\title{
Forests, Tribals and the Voice of Dissent: The Story of a Social Actor
}

Miss Namami Sharma ${ }^{+}$

Abstract

This is a biography of an activist who has been working in the interiors of Madhya Pradesh with the indigenous people. He has been living amongst the tribal communities and has contributed significantly in the people's struggle for resource rights. He is one of the very few activists who has been quoted by different writers but is not written about. This article, thus, makes a humble endeavour to trace his life and his commitment towards the cause of tribal rights.

Key words: activist, tribal communities, people's movements, tribal rights

\footnotetext{
${ }^{\dagger}$ Department of Social Work, Delhi University, India [Email: namamisharma@gmail.com] 


\section{Introduction}

'A voice from the ether becomes the voice of the God'- anonymous

In the poem 'Satpura ke Ghane Jungle' (Through the dense forests of the Satpuras) the poet Bhavani Prasad Mishra, takes one through the dense green mystic forests of the Satpura mountain range and gives the visions of the eclectic wildlife in the jungles. In the romantic visualisations of the forest, one would imagine the wild as 'an inviolate space' immersed in 'wildernesses'. Seldom would the imagination include the indigenous groups in the community who are often found in a very vulnerable position. In these remote forests of the Satpura Hill Range in Central India, the voice of a young man has been able to revive the nature-culture equation among the Baiga tribes, which has been long lost. This paper makes a humble attempt to trace the endeavours of this young man, who by means of his 'silent ways', found them their voices.

\section{Geographical location}

Here, the area is Baiga Chak, ${ }^{1}$ which is located in the state of Madhya Pradesh (MP) in the central Indian plains. The name of this young man is Balwant Rahangdale popularly known as Balwantji or Balwant bhai (brother). Balwantji works in the tribal $^{2}$ (Xaxa, 1999) block of Samnapur, which is situated in the district of Dindori in MP. Over the years, Samnapur has witnessed many researchers and journalists come to the area and cover the issues of the Baiga tribe with the help of Balwantji. Invariably his 'quotes' and 'comments' figure in most of those articles without him coming to the foreground (Pallavi, 2012; Desor, 2013). Many might not agree with him being called an

\footnotetext{
${ }^{1}$ Baiga Chak is a congregation of 52 villages located in the district Dindori of the state MP. These villages were settles in the later part of 19th century as a means of confining their shifting agriculture or bewar to a limited area.

${ }^{2}$ Although, the term 'tribe' has been debated much in academic parlance, however, 'this term of administrative convenience have been adopted by the tribals themselves....attaching self -esteem and pride to the same' (Xaxa, 1999: 3589).
}

'active' activist but his engagement with the tribals of Dindori has triggered a silent movement, which could bring back their lost voices.

The author came to learn about this young man during one of her field visits in the area. Before that, she did come across several magazine and newspaper articles quoting his statements in the context of the Baiga struggle in Dindori. However, only on the field visit, did she realise that the 'Balwant' quoted in the articles and 'Balwant Bhai' referred, as by the villagers is the same person. During the visit, she could comprehend the impact this person had on the villagers in making them aware of their rights. In the course of the first meeting, the author witnessed a persona of commitment and heard an untold story, which deserves to be told.

\section{Life sketch of Balwantji}

Balwantji is a person who could leave a lasting impression at the very first meeting. Donned with grey hair and armed with a soft voice, he speaks passionately about the Baiga tribe and their struggle for resource rights. He has been working in the Baiga Chak area since last 15 years and all this while he has been in the background of all the people's struggles for resource rights in the area.

To highlight the significance of Balwantji's work, it is important to give a background of the Baigas. The Baigas are indigenous people found in the central Indian plains of the Indian subcontinent. The tribe is a very shy one and used to dwell in the forests of the Satpura hill range. Their relationship with nature has been very intricate but the forest policies and legislations have failed to take an account of the same. The contemporary wildlife conservation discourses often seems to be considering 'human' as an intruder in the constructed 'inviolate spaces' without taking into account the intrinsic value of nature that indigenous cultures adhere to (Soule and Terborgh, 2009; Madhusudan, 2005; Kabra, 2006).

MP has been the place of inception of many a movements and struggles in India. However, 
the Baigas has often found themselves in the midst of these movements without understanding the purpose of the same. It would not be wrong to say that, most of the struggles were at the larger frame of tribal rights and the Baigas found it difficult to comprehend the same in their immediate context.

The journey of Balwantji began in the year 1995. It was spring season in another remote village in the district of Balaghat and the boys in his village were having a relaxed time after their high school exams. Balwantji was a pupil then and was enjoying the post-examination lull. However, he was reading literature on tribal movements during that time which triggered certain questions in his zealous mind. He was born to a farmer in a village in Balaghat and was one among eight siblings. He was very fond of dreaming and visioning but often he would be clueless on how to go about realising them. Nevertheless, he sought solace in books and became a voracious reader. Some of the readings would answer his queries while others would raise even more questions.

In 1995, a programme was launched by the MP government called the Madhya Pradesh Forestry Project. This project commenced in India in 1995 with a loan of 58 million USD. The first four-year phase of the project ended in December 2009. The objectives of the project were appropriately articulated as highlighting the importance of community participation in biodiversity conservation (Bramhane and Panda, 2000). The overall goal of the programme being biodiversity conservation, the project focussed upon the extension of protected and reserved forest areas. The project rejected the intrinsic existence of the indigenous people of the region, leading to the relocation of several villages. The Kanha National Park being one of the significant parks was also under scrutiny. The park was $940 \mathrm{sq}$. kms and now it was increased to $1060 \mathrm{sq}$. kms. With this expansion, around 161 villages across three districts namely, Mandla, Rajnandgaon and Balaghat were impacted. Many relocation and rehabilitation programmes were going on but one could see several discrepancies in the implementation of the orders. People rose up in protests and it was during this time that Balwantji's young mind decided to seek answers to his queries. He could never understand how the state could conserve forests without the involvement of people. In his understanding, people were an intrinsic part of any ecosystem. His village was one of the affected ones and he could sense the plight of the people on the face of the tenuous relocations. People were literally uprooted from their roots and planted in the middle of nowhere. There was a strong consensus to protest the new moves of the state. A movement had begun and a padyatra (street march) called the Jungle Jeevan Bachao Yatra (Save Forest, Save Life) was initiated by a few leading tribal activists of those times. Around 15 individuals had set out on a $15000 \mathrm{~km}$ walkathon through the protected areas and national parks. Meera lyer (1995) terms it as a 'missionary voyage', wading through the 'indigenous waters' and trying to address the issues of the people on the face of the draconian forest projects. There was a very dynamic activist called Kusum Karnik who was leading the protest in the district of Balaghat in MP, which was home to Balwantji. On one of the many rallies, he was standing by the side of the road as a spectator and watching the rally pass by under the efficient leadership of Kusum Tai. In Balwantji's words, 'My heart pulled me .....and the next moment I found myself in the middle of it all .... and now I am yet to get out of it'. He was just 14 year old and since then he has been associated with the movement. He joined the rallies and helped in participating and conducting many after that. The cause remains the same and so does the slogan. 'Jal Jungle aur Zameen, Yeh Hain Janta ke Aadhin' (Land, Water and Forests: These are solely under the People's Authority) still rings in his heart, he says.

There was a strong movement on the forests rights going on during the late nineties in MP. It was a people's movement and the collective was popularly known as Ekta Parishad (Forum of Unity). Balwantji was a part of it and under 
the guidance of many eminent activists; he continued participating in the activities of the struggle. To address the larger issue of relocation and rehabilitation, the Ekta Parishad launched a six-month padyatra on December 10,1990 . The padyatra began in the extreme west of MP and ended in Rajgarh, which was a part of the then eastern MP and now is located in Chhattisgarh. The main issue was that of relocation and rehabilitation of the tribal communities from the newly-demarcated protected areas. The struggle was also aiming at ensuring the rights on their resources. After the padyatra, to his disappointment, the Ekta Parishad members got into an agreement with the government, which eventually snapped the movement at a pre-matured stage. This pushed Balwantji to a phase of disillusionment, which led him to think of his future strategies. He says that he realised that grandiosity has its own limitations. He tried to re-examine the statement 'small is beautiful' in the context of his work. Taking small steps at a time from a micro level was thought to be more realistic, he explains. He then decided to realise his 'dreams of change' from an inconspicuous locale and resolved to work with the people.

He says he was always mesmerised by the rich culture of the Baigas. From his field experiences, he also realised that in the race of development, the Baigas have been left far behind. On one hand, if a group of anthropologists romanticises the Baiga culture, the policy makers very conveniently chooses to overlook that very culture. With this realisation, as stated above, he chose a very remote part of MP called the Baiga Chak to work in. This area was being demarcated by the British in the late $19^{\text {th }}$ century as a part of the process of settling down the Baiga community from Swidden ${ }^{1}$ to settled agriculture. Since then, the Baigas are residing in the area but hardly have been able to find ground on the face of the draconian forests laws.

\footnotetext{
${ }^{1}$ Swidden agriculture refers to shifting agriculture where the trees and vegetation in a patch of forest is lopped and burnt. Seeds are generally broadcasted in the cleared patch. This form of cultivation is popularly considered damaging to the forest cover.
}

During his first stint in the area, he settled down in a hut within a Baiga village known as Dhaba. He realised that it is high time; the Baigas moved beyond the pages of anthropological accounts and enter the realm of social justice. As mentioned before, the Baigas are shy by nature. Moreover, the limited exposure and the almost stunted development in the area have brought them to a state of utter ignorance. The Baigas living in the region had no awareness of exercising their fundamental rights. They were living a life totally at the mercy of the Forest Department. As mentioned above, Balwantji entered the area almost 15 years ago with the intention of understanding the issues and carrying them forward with a renewed vigour. His approach was totally bottom-up and he began with 'inculcating a culture of questioning'. He says, the Baigas were suppressed and subjugated for so many decades that they had never thought exercising their will.

Balwantji continued staying in Dhaba and developed a good rapport with the community. On one occasion he once learnt that, the Forest department (FD) is proposing to make a pond in the village and the site has also been decided by the forest officials without taking the opinion of the villagers into consideration. This has been a regular practice and the villagers were used to the FD making structures, which eventually proved to be not of much use to them. Balwantji was witnessing everything very closely. He approached the people in the village and took their suggestion on deciding on an appropriate site for the pond. The people chose a site and explained very well on how a pond in the said site would be of optimal use to the village. He then coaxed the people to make the same suggestion to the officials. Next day the officials came and as decided a few persons from the village went forward and made their suggestions. The officials were perturbed and called off the work. This again caused some differences in opinion amongst different section of people. Some started blaming the rest and also Balwantji, for being instrumental in halting the work since this work was one of their few sources of income. The next day the 
officials came with a hired tractor to till the land. Three women went forward and lay down on the ground obstructing the tractor. This made the officials leave in a huff. They then came a few days later only to start work at the said site. This was the first time people had gathered courage to speak against the authorities. This 'voice of dissent' was recorded in the history of Baiga Chak as the 'tractor virodh' (tractor protest).

Gradually, Balwantji was observing that the Baigas has immense dependency on the forest resources but were not able to exercise any rights over the same. He felt the urgency to work on the same. He stayed in the background and started mobilising people. His strategies were not in the form of protest, rallies or slogans. Rather, he believed in 'insitu expression of dissent', where he mobilised people within their smaller environments. This belief stemmed out from the disillusioned he underwent during the six-month rally, which had happened with Ekta Parishad. People had a very simple question to raise, 'If the FD is protecting forests in such a big way, where has all the species gone?' After much dialogue in the villages, the people took up the issue of seriously protecting their areas. The Baigas were culturally connected to nature and Balwantji could stir the people's ecological consciousness, which remained suppressed for decades. He worked with the people of one village and the rest followed. There was a collective voice from Baiga Chak. On one occasion, every household of a village decided to adopt a tree. When coupe operation by the FD took place, each one of them hugged the trees thus avoiding the 'axe' of the FD's. On another occasion, people from another village tied rakhis ${ }^{1}$ on 'Raksha Bandhan' to the trees promising to protect each one of them. The people in the villages worked relentlessly to manage forest fires and the people's efforts were applauded. Balwantji had to come to the front to dialogue with the state

\footnotetext{
${ }^{1}$ Rakhi is a symbolic thread tied by the sisters around the wrist of their brothers, signifying a bond of love and protection.
}

representatives. The FD was also surprised and was bound to appreciate the initiatives of the Baigas.

By the year 2006, the Forest Rights Act (FRA) came into force. This legislation opened the doors of hope for the Baigas in ensuring their resource rights. Institutions were evolved at the village level for the purpose of forest protection. Though the FD came up with various extracting operations, the villagers went on a 'non-cooperation' mode. Norms and regulations were laid down to protect their forests and this time the rules were in sync with the tribal cultural beliefs. Balwantji was very prompt in documenting the indigenous culture and often he pointed out the relevance of the same to the people. He started representing the Baigas and their causes in many national forums. He was seldom heard. However, he was able to convey the issues of the Baigas in larger platforms like the National Forum of Forest People and Forest Workers. He was also a part of the national review team of community forest rights and deliberated actively on the issues.

With the coming of the FRA, Balwantji facilitated the people of four Baiga Chak villages to file for community rights. In 2013, Baiga Chak marked history. A total of 15000 acres were brought under community forests rights across four villages. The Baigas could exercise their rights over the resources, but most importantly, the struggle gave them the confidence of voicing out their rights. Newspaper reports spoke at length about the success stories, though a few ever came to know about the man behind it. The Baigas, who had traversed through various image constructions over the time, has managed to get back his original and most deserved status of a 'nature's man'. A single man's voice truly became the voice of the Gods in Baiga Chak.

\section{About the Author}

The author is presently pursuing her PhD from the Department of Social Work, University of Delhi, in which she is exploring the communitybased forest conservation practices of the Monpa tribe in Arunachal Pradesh. Prior to this, 
she was working in the field of forest conservation and tribal rights in the states of Madhya Pradesh and Chhattisgarh. Her quest for research emerged out of her lived experiences in the field. She is interested in exploring the equation of nature and culture through the lens of cultural ecology.

\section{References}

Bramhane. G. and Panda, B.K. (2010).

Workshop on indigenous peoples, forests and the World Bank: Policies and practice, available at:

http://www.forestpeoples.org/sites/fpp/files/p ublication/2010/08/wbipsmadhyapradeshmay0 Oeng.pdf (accessed September 03, 2013)

Desor. S. (ed). (2013).Community Forest Rights under Forest Rights Act: Citizen's report, 2013,

Iyer, M. (1995, March 31). Forests march. Down to Earth, available at http://www.downtoearth.org.in/node/27700 (accessed September 05, 2013)

Kalpavriksha, P. and Vasundhara, B. with Oxfam India, Delhi, On behalf of community forest rights learning and advocacy process, available at

http://www.kalpavriksh.org/images/LawsNPoli cies/Community\%20Forest\%20Rights\%20under \%20FRA\%20Citizens\%20Report\%202013.pdf (accessed September 04, 2013)

Kabra, A. (2006). Wildlife protection: Reintroduction and relocation. Economic and Political Weekly, 41, 1309-1311

Madhusudan, M. D. (2005). Of rights and wrongs: Wildlife conservation and the tribal bill. Economic and Political Weekly, 40, 48934895

Pallavi.A. (2012, March 6). Baigas cheated of community forest rights. Down to Earth, available at http://www.downtoearth.org.in/content/baiga s-cheated-community-forest-rights (accessed September 05, 2013)

Shahabuddin, G., Kumar, R., \& Shrivastava, M. (2007). Creation of 'Inviolate Space': Lives, livelihoods and conflict in Sariska Tiger Reserve. Economic and Political Weekly , 42, 1855-1862
Soule, M. E., \& Terborgh, J. (1999). Continental conservation. Washington DC: Island Press

Xaxa, V. (1999). Tribes as indigenous people of India, Economic and Political Weekly, 34(51), 3589-3595 